\title{
Rевевкин автісі: : Evaluation of tomato hybrids for resistance to leaf curl virus
}

Article Chronicle:

Received :

13.07.2017;

Accepted :

28.07.2017

KeY WORDS:

Tomato, TLC VD,

Tolerance, Peroxidase, Poly phenol oxidase
Author for correspondence :

\section{K. SUNDHARAIYA}

Tamil Nadu Agricultural

University, COIMBARORE

(T.N.) INDIA

See end of the article for

authors' affiliations
SUMMARY : Tomato leaf curl virus disease (TLCVD) is a serious problem in cultivation and production of tomato in India. The disease is widespread in tomato during the summer season in South India and autumn in North India. In South India, the incidence of TLCVD in susceptible cultivars increases rapidly from 27 to 90 per cent causing yield losses exceeding 90 per cent.The objective of this study was to screen the two newly synthesized tomato $\mathrm{F}_{1}$ hybrids viz., CLN 2123A X HN $\mathrm{H}_{2}$ and $\mathrm{HN}_{2} \mathrm{X}$ CLN $2123 \mathrm{~A}$ to find out the leaf curl virus resistance along with their parents and check varieties/hybrids. The experiment was conducted both under natural epiphytotic condition as well as glass house condition through whitefly mediated inoculation. The experiment was laid out in a Randomized Block Design and replicated thrice. The results revealed that the newly synthesized hybrids CLN 2123A X HN $\mathrm{H}_{2}$ and $\mathrm{HN}_{2}$ X CLN 2123A registered low level of percent of disease infection under artificial and natural epiphytotic conditions and these varieties showed high values of defense enzymes viz., peroxidase and poly phenol oxidase both under artificial and natural epiphytotic conditions. The same hybrids also registered higher plant height, number of branches per plant, number of fruits per plant and yield per plant under field condition inferred that these two synthesized hybrids are tolerant tomato leaf curl virus. These two newly synthesized hybrids were on par with tomato leaf curl virus resistant check hybrid Lakshmi for tomato leaf curl virus disease incidence.

How to cite this article : Sundharaiya, K., Jansirani, P., Karuthamani, M. and Sathish, G. (2017). Evaluation of tomato hybrids for resistance to leaf curl virus. Agric. Update, 12(TECHSEAR-3) : 777-783; DOI: 10.15740/ HAS/AU/12.TECHSEAR(3)2017/777-783. 